\title{
Conceptions of the pathophysiology of happy hypoxemia in COVID-19
}

\author{
Sebastiaan Dhont ${ }^{1^{*}}$ (D) Eric Derom ${ }^{1,2}$, Eva Van Braeckel ${ }^{1,2}$, Pieter Depuydt ${ }^{1,3}$ and Bart N. Lambrecht $t^{1,2,4}$
}

\begin{abstract}
In their letter-to-the-editor entitled "Misconceptions of pathophysiology of happy hypoxemia and implications for management of COVID-19", Tobin et al. (Respir Res 21:249, 2020) debated our views on happy hypoxemia in COVID19 (Respir Res 21:198, 2020). We thank the authors for their interesting comments and alternative viewpoints, and we would like to clarify several important aspects raised.
\end{abstract}

Keywords: COVID-19, Happy hypoxemia, Respiratory failure, Gas exchange, Cytokine storm

\section{Letter}

We read with interest the letter-to-the-editor by Tobin, Jubran and Laghi concerning our article on happy hypoxemia in COVID-19 [1, 2]. The authors challenged our narrative review with some interesting thoughts.

We agree with Tobin et al. [1] that "the essential point about happy hypoxemia is that patients can be profoundly hypoxic and yet exhibit no abnormality in breathing pattern". This is worrying indeed, as the severity of hypoxemia is independently associated with inhospital mortality and in particular of concern among patients with chronic compromised organ perfusion such as ischemic heart disease [3-5]. However, in our experience, subtle changes in breathing pattern may serve as early warning signs of impending hypoxemic respiratory failure in COVID-19. The respiratory drive shifts minimally in mild hypoxemia, but when arterial oxygen tension drops below a critical threshold, a rise in minute volume does occur [6-9]. That is why we stressed the importance of interpreting pulse oximetry results in the light of the respiratory rate. The oxyhemoglobin-dissociation curve may indeed shift to the right when COVID19 disease progresses [1]. Although mainly a theoretical

\footnotetext{
*Correspondence: sebastiaan.dhont@ugent.be

${ }^{1}$ Department of Internal Medicine and Pediatrics, Ghent University, Corneel Heymanslaan 10, 9000 Ghent, Belgium
}

Full list of author information is available at the end of the article concept-some authors claim a leftward shift [10]-the mechanisms and importance of this phenomenon require further investigation.

Tobin and colleagues [1] state that there is no evidence for patient self-inflicted lung injury (P-SILI), neither in COVID-19 nor in other conditions leading to acute respiratory failure. In 2010, Papazian et al. revealed that early administration of neuromuscular blocking agents improved 90-day survival in ARDS [11]. The mechanisms underlying this beneficial effect remain controversial, but the potential risk of spontaneous breathing efforts (also investigated in non-intubated patients $[12,13])$ and the subsequent need for prevention of these efforts during mechanical ventilation have been highlighted and extensively discussed. Experimental observations have pointed out that P-SILI in humans can lead to pulmonary edema following airway obstruction, due to large variations in pleural pressure $[14,15]$. This mechanism may also be responsible for pulmonary edema resulting from re-expansion of a pneumothorax and edema formation in a minority of patients experiencing a severe asthma attack $[16,17]$. Additionally, the spontaneous occurrence of pneumomediastinum in non-intubated patients with COVID-19 may be an example of a so-called self-inflicted lung injury $[18,19]$. In closing, we believe that P-SILI remains an interesting hypothesis in the disease progression of COVID-19 [20]. Otherwise, we agree with Tobin and colleagues $[1,21]$ that there is insufficient evidence to

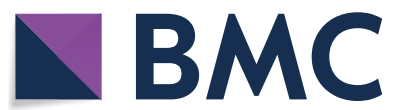

(c) The Author(s) 2021. This article is licensed under a Creative Commons Attribution 4.0 International License, which permits use, sharing, adaptation, distribution and reproduction in any medium or format, as long as you give appropriate credit to the original author(s) and the source, provide a link to the Creative Commons licence, and indicate if changes were made. The images or other third party material in this article are included in the article's Creative Commons licence, unless indicated otherwise in a credit line to the material. If material is not included in the article's Creative Commons licence and your intended use is not permitted by statutory regulation or exceeds the permitted use, you will need to obtain permission directly from the copyright holder. To view a copy of this licence, visit http://creativecommons.org/licenses/by/4.0/. The Creative Commons Public Domain Dedication waiver (http://creativecommons.org/publicdomain/zero/1.0/) applies to the data made available in this article, unless otherwise stated in a credit line to the data. 
warrant premature intubation in order to prevent P-SILI in COVID-19, and that there are much simpler measures to tackle (happy) hypoxemia, such as providing supplemental oxygen.

Tobin et al. [1] ask if there is evidence indicating that specific measures will ameliorate cytokine storm and if tackling these targets will benefit COVID-19 patients. Although thoughts on immunomodulatory therapeutic targets in COVID-19 were only mentioned in the margin of our review on happy hypoxemia, data on the role of cytokine release syndrome (CRS) have been increasingly reported since. Increased levels of pro-inflammatory cytokines (e.g., IFN $\alpha$, IFN $\gamma$, IL-1 $\beta$, IL-6, IL-12, IL-18, IL-33, TNF $\alpha$, TGF $\beta$ ) and chemokines (e.g., CXCL10, CXCL8, CXCL9, CCL2, CCL3, CCL5) are associated with pulmonary inflammation and ARDS in patients infected by SARS and MERS-CoV infections [22, 23]. Huang et al. reported that COVID-19 patients also show high titers of these cyto- and chemokines and, more importantly, the cytokine release syndrome (CRS) seem to emerge as a main factor driving a more severe clinical course [24]. A multicenter study in China revealed that higher levels of serum IL-6 were correlated with fatal outcome in COVID-19 [25]. Similar studies by Gao et al. and Chen et al. reported that levels of IL-10, IL-6 and TNF- $\alpha$ were higher in severe COVID-19 $[25,26]$. The main contributors to the interplay of the CRS seem to be IL-1, IL- 6 and TNF- $\alpha$ and several biological agents targeting these cytokines are being extensively studied in COVID-19 [27]. Tocilizumab, for example, is a humanized monoclonal antibody that binds IL- 6 receptors and has proven to be valuable in treatment of cytokine storm triggered by chimeric antigen receptor T-cell therapy [27]. Encouraging results have been reported on its use in severe COVID-19 on length of ICU stay, ventilationfree survival, and also on oxygenation parameters [27, 28]. These findings explain why we eagerly await the final results of ongoing international randomized trials, that not only look at blockade of individual cytokines, but also at combined IL-1 and IL-6 blockade (e.g. NCT04320615, NCT04372186, NCT04331808 and NCT04330638) [28].

In conclusion, we thank the authors for their critical comments. Our main intention was to provide a thoughtprovoking review on the potential mechanisms leading to the phenomenon of happy hypoxemia in COVID19, more than providing therapeutic guidelines, which should always be based on scientific evidence.

\section{Abbreviations}

COVID-19: Coronavirus disease 2019; MERS: Middle East Respiratory Syndrome; SARS: Severe Acute Respiratory Syndrome Coronavirus; ICU: Intensive Care Unit; P-SILI: Patient self-inflicted lung injury; ARDS: Acute respiratory distress syndrome; IL: Interleukin; TNF: Tumor necrosis factor; TGF: Transforming growth factor; CXCL: C-X-C motif chemokine ligand; CCL: Chemokine (C-C motif) ligand.

\section{Acknowledgements}

Not applicable.

\section{Authors' contributions}

All authors read and approved the final manuscript.

Availability of data and materials

Not applicable.

Ethics approval and consent to participate

Not applicable.

\section{Consent for publication}

Not applicable.

\section{Competing interests}

The authors declare that they have no competing interests.

\section{Author details}

${ }^{1}$ Department of Internal Medicine and Pediatrics, Ghent University, Corneel Heymanslaan 10, 9000 Ghent, Belgium. ${ }^{2}$ Department of Respiratory Medicine, Ghent University Hospital, Ghent, Belgium. ${ }^{3}$ Department of Intensive Care Medicine, Ghent University Hospital, Ghent, Belgium. ${ }^{4}$ VIB-UGent Center for Inflammation Research, Ghent, Belgium.

Received: 18 December 2020 Accepted: 4 January 2021

Published online: 08 January 2021

\section{References}

1. Tobin MJ, Jubran A, Laghi F. Misconceptions of pathophysiology of happy hypoxemia and implications for management of COVID-19. Respir Res. 2020. https://doi.org/10.1186/s12931-020-01520-y.

2. Dhont S, Derom E, Van Braeckel E, Depuydt P, Lambrecht BN. The pathophysiology of "happy" hypoxemia in COVID-19. Respir Res. 2020. https:// doi.org/10.1186/s12931-020-01462-5.

3. Xie J, Covassin N, Fan Z, Singh P, Gao W, Li G, et al. Association Between Hypoxemia and Mortality in Patients With COVID-19. Mayo Clin Proc. 2020;0. https://linkinghub.elsevier.com/retrieve/pii/S0025619620303670.

4. Fuglebjerg NJU, Jensen TO, Hoyer N, Ryrsø CK, Madsen BL, Harboe ZB. Silent hypoxia in patients with SARS CoV-2 infection before hospital discharge. Int J Infect Dis. 2020;99:100-1.

5. Vlachakis PK, Tentolouris A, Kanakakis I. Concerns for management of STEMI patients in the COVID-19 era: a paradox phenomenon. J Thromb Thrombolysis. 2020. https://doi.org/10.1007/s11239-020-02236-y.

6. Easton PA, Slykerman LJ, Anthonisen NR. Ventilatory response to sustained hypoxia in normal adults. J Appl Physiol (1985). 1986;61:906-11.

7. Tobin MJ, Laghi F, Jubran A. Ventilatory failure, ventilator support, and ventilator weaning. Compr Physiol. 2012;2:2871-921.

8. Mekjavic IB, Eiken O, LaPrairie A, Banister EW. The pattern of breathing during hypoxic exercise. Eur J Appl Physiol Occup Physiol. 1987:56:619-22.

9. Moosavi SH, Golestanian E, Binks AP, Lansing RW, Brown R, Banzett RB Hypoxic and hypercapnic drives to breathe generate equivalent levels of air hunger in humans. J Appl Physiol. 2003;94:141-54.

10. Vogel DJ, Formenti F, Retter AJ, Vasques F, Camporota L. A left shift in the oxyhaemoglobin dissociation curve in patients with severe coronavirus disease 2019 (COVID-19). Br J Haematol. 2020;191:390-3.

11. Papazian L, Forel J-M, Gacouin A, Penot-Ragon C, Perrin G, Loundou A, et al. Neuromuscular blockers in early acute respiratory distress syndrome. N Engl J Med. 2010;363:1107-16. https://doi.org/10.1056/NEJMo a1005372.

12. Brochard L, Slutsky A, Pesenti A. Mechanical ventilation to minimize progression of lung injury in acute respiratory failure. Am J Respir Crit Care Med. 2017. https://doi.org/10.1164/rccm.201605-1081CP. 
13. Goligher EC, Jonkman AH, Dianti J, Vaporidi K, Beitler JR, Patel BK, et al Clinical strategies for implementing lung and diaphragm-protective ventilation: avoiding insufficient and excessive effort. Intensive Care Med. 2020. https://doi.org/10.1007/s00134-020-06288-9.

14. Price SL, Hecker BR. Pulmonary oedema following airway obstruction in a patient with Hodgkin's disease. Br J Anaesth. 1987;58:518-21.

15. Willms D, Shure D. Pulmonary edema due to upper airway obstruction in adults. Chest. 1988;94:1090-2.

16. Childress ME, Moy G, Mottram M. Unilateral pulmonary edema resulting from treatment of spontaneous pneumothorax. Am Rev Respir Dis. 1971;104:119-21.

17. Stalcup SA, Mellins RB. Mechanical forces producing pulmonary edema in acute asthma. N Engl J Med. 1977;297:592-6. https://doi.org/10.1056/ NEJM197709152971107.

18. Gorospe L, Ayala-Carbonero A, Ureña-Vacas A, Fra Fernández S, MuñozMolina GM, Arrieta P, et al. Spontaneous pneumomediastinum in patients with COVID-19: a case series of four patients. Arch Bronconeumol. 2020;56:754-6.

19. Zhou C, Gao C, Xie Y, Xu M. COVID-19 with spontaneous pneumomediastinum. Lancet Infect Dis. 2020;20:510.

20. Hyman JB, Leibner ES, Tandon P, Egorova NN, Bassily-Marcus A, Kohli-Seth $R$, et al. Timing of intubation and in-hospital mortality in patients with coronavirus disease 2019. Crit Care Explor. 2020;2:e0254. https://journals. Iww.com/ccejournal/Fulltext/2020/10000/Timing_of_Intubation_and_ In_Hospital_Mortality_in.45.aspx.

21. Tobin MJ, Laghi F, Jubran A. Caution about early intubation and mechanical ventilation in COVID-19. Ann Intensive Care. 2020:10:78.
22. Coperchini F, Chiovato L, Croce L, Magri F, Rotondi M. The cytokine storm in COVID-19: an overview of the involvement of the chemokine/ chemokine-receptor system. Cytokine Growth Factor Rev. 2020;53:25-32.

23. Channappanavar R, Perlman S. Pathogenic human coronavirus infections: causes and consequences of cytokine storm and immunopathology. Semin Immunopathol. 2017. https://doi.org/10.1007/s00281-017-0629-X.

24. Huang C, Wang Y, Li X, Ren L, Zhao J, Hu Y, et al. Clinical features of patients infected with 2019 novel coronavirus in Wuhan, China. Lancet. 2020;395:497-506

25. Ruan Q, Yang K, Wang W, Jiang L, Song J. Clinical predictors of mortality due to COVID-19 based on an analysis of data of 150 patients from Wuhan, China. Intensive Care Med. 2020. https://doi.org/10.1007/s0013 4-020-05991-x

26. Gao Y, Li T, Han M, Li X, Wu D, Xu Y, et al. Diagnostic utility of clinical laboratory data determinations for patients with the severe COVID-19. J Med Virol. 2020;92:791-6. https://doi.org/10.1002/jmv.25770.

27. Ragab D, Salah Eldin H, Taeimah M, Khattab R, Salem R. The COVID-19 cytokine storm; what we know so far. Front Immunol. 2020;11:1446. https ://doi.org/10.3389/fimmu.2020.01446/full.

28. Parr JB. Time to reassess Tocilizumab's role in COVID-19 pneumonia. JAMA Intern. Med. 2020. Available from: https://jamanetwork.com/.

\section{Publisher's Note}

Springer Nature remains neutral with regard to jurisdictional claims in published maps and institutional affiliations.
Ready to submit your research? Choose BMC and benefit from:

- fast, convenient online submission

- thorough peer review by experienced researchers in your field

- rapid publication on acceptance

- support for research data, including large and complex data types

- gold Open Access which fosters wider collaboration and increased citations

- maximum visibility for your research: over $100 \mathrm{M}$ website views per year

At $\mathrm{BMC}$, research is always in progress.

Learn more biomedcentral.com/submissions 